\title{
WILLOW PTARMIGAN IN THE BOREAL FOREST OF THE PRAIRIE PROVINCES
}

\author{
E. OTTO HÖHN, 11511-78 Avenue, Edmonton, Alberta. T6G 0N4
}

Willow Ptarmigan are annual winter visitors to the boreal forest zone of the prairie provinces. Experiences during a number of winter visits to points in northern Alberta and Saskatchewan suggested to me that ptarmigan only occurred in numbers at any given locality during a restricted part of each winter. To determine whether there were in fact definite patterns of seasonal prevalence which, further, might show regional differences within the large wintering area, I sent a questionnaire dealing with this and other topics about these birds to wildlife officers of the settlements shown in Figure 1. Localities from which reports were received were divided into a southern

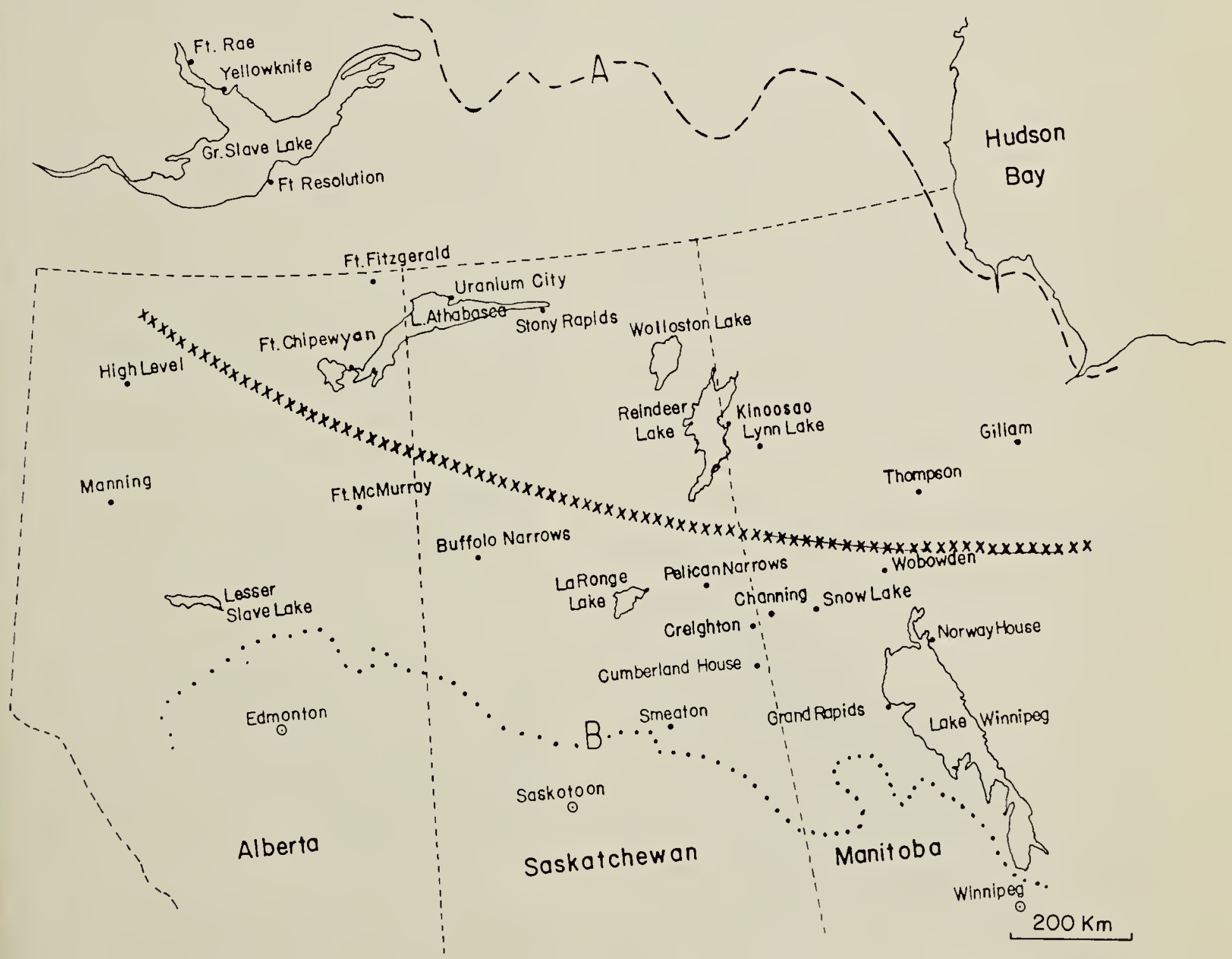

Figure 1. Map of the Canadian prairie provinces and the Great Slave Lake area indicating localities from which reports on the seasonal prevalence of Willow Ptarmigan were received. Line $A$ (dashed) is the northern limit of the boreal forest. Line B (dotted) is the southern limit of boreal forest. The crosses give the line of demarcation between southern and northern reporting areas. 
zone near the southern edge of the boreal forest and a northern zone well within it (Fig. 1). Information obtained directly from residents in some areas and my own limited observations were also considered. Forty-three replies to questionnaires dealing with one or more of the winters of 1971-72, 197475 and 1975-76 were received.

\section{Seasonal prevalence in winter}

The questionnaire asked during what period(s) six (an arbitrary number) or more ptarmigan per day were seen. Sixteen (out of 21 ) reports from the southern zone reported ptarmigan in such numbers only in mid-winter (i.e. November-February). There was only one April report and reports of two periods of prevalence during the same winter.

From the northern zone only 4 out of 22 reports showed observations restricted to mid-winter. Ten of the "northern reports" recorded two separate periods of prevalence in the same winter, e.g. November 20 - December 30 and February 20 - March 30 at Kinoosao, Saskatchewan in 1971-72. There were seven reports of ptarmigan seen in some numbers as late as April and one in May.

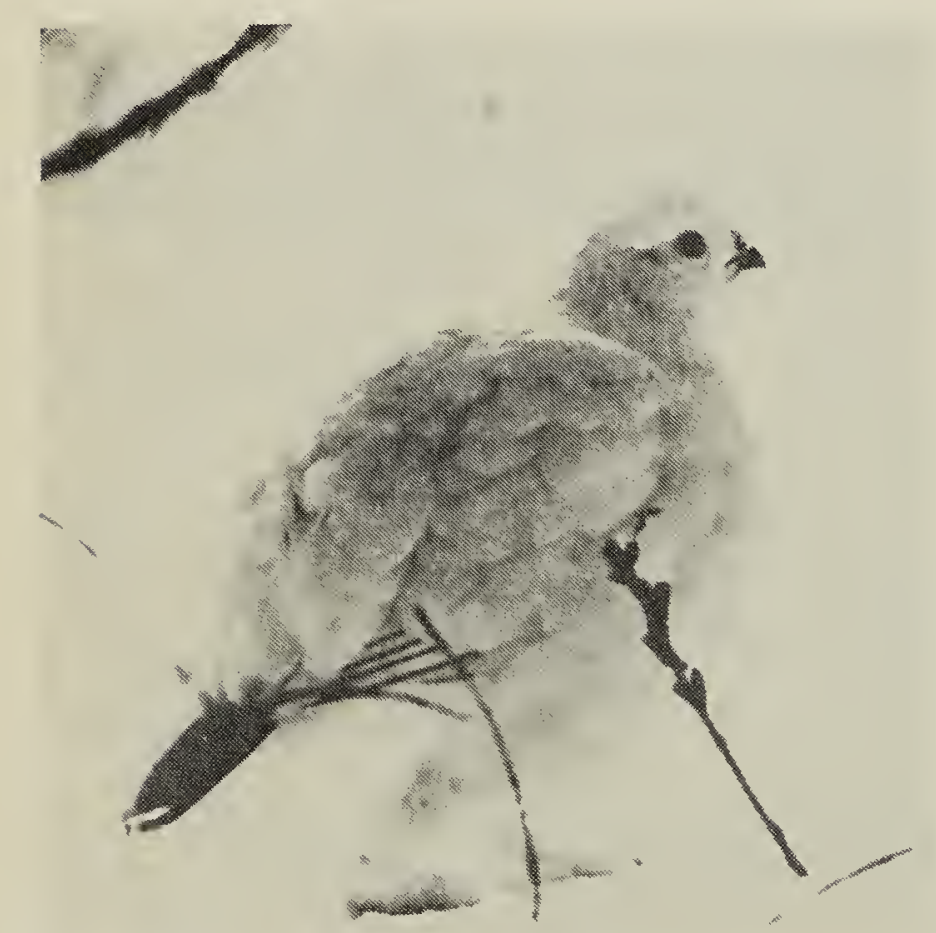

Willow Ptarmigan near Uranium City, Saskatchewan

Dr. J.G. Beatty
This information indicates that in the northern area, ptarmigan are often numerous only during their southward fall passage and again during their northward spring migration. Only about one fifth of the reports from the northern area indicate that occurrence in numbers is restricted to mid-winter. In the southern area, the birds are generally prevalent only in mid-winter, between the fall and the spring migrations.

It is well known that ptarmigan populations are subject to considerable fluctuation. The reports for the winter of 1974-75 showed that 1974 was a year of below average numbers for the area under consideration. Patterns of seasonal prevalence in the forest zone were, nevertheless, much as in other years.

\section{Sex ratios}

Weeden has shown that in Rock and Willow Ptarmigan in Alaska males winter near the breeding area, whereas females moved further south into forested areas which these species use only in winter. ${ }^{11}$ To obtain information on such partial segregation of the sexes in Willow Ptarmigan in the area under consideration, data on sex ratios was sought in questionnaires and was supplemented from birds collected by myself, from museum specimens and from the literature.

The data summarized in Table 1 show that in the southern zone of the boreal forest over 3 times as many females as males were collected but that both sexes were represented in equal numbers in the northern zone.

Overall the sexes in this species are present in approximately equal numbers. Jenkins et al. reported $55.9 \%$ males in the conspecific ${ }^{\star}$ RedGrouse. ${ }^{7}$

* Conspecific - of the same species, applied to individuals or to populations of the same species. 
Table 1. SEX RATIOS OF WILLOW PTARMIGAN COLLECTED IN WINTER.

Males

Females

Northern Boreal Forest: Western Great Slave Lake area;

Ft. Smith, N.W.T.; northern Alberta and Saskatchewan

Southern Boreal Forest: North-central Alberta,

Saskatchewan and Manitoba*
43

42

20
74

*The sex of 30 birds collected at Creighton was determined by wing length; 2 in all others, the gonads were inspected.

Since females predominated in the southern zone, while the sexes were represented in equal numbers in the northern forest zone, males must predominate in the remaining wintering areas of the species, the tundra. Porsild's report that in winter many more males than females were shot in the MacKenzie Delta support this view, as does the preponderance of males at the northern edge of the forest zone in the Brooks range in Alaska observed by West et al. ${ }^{814}$

Factors which may be involved in the different distances to which the sexes migrate are considered in the discussion.

\section{Migratory flights}

Ptarmigan are not often seen in evident migratory flights, however, the limited number of observations available for the area, are predominantly of northeastward flights in spring and southwestward ones in fall; rather than along a north-south axis as might have been expected: Available observations are summarized below; no authority is cited for observations based on questionnaire replies.

\section{Spring movements}

FORT FITZGERALD, ALBERTA:

Soper observed a succession of large flocks flying over the settlement in a northeasterly direction 23 April 1933. ${ }^{10}$
URANIUM CITY AREA, SASKATCHEWAN: Mr. S. McDonald, a local trapper, reports that from late March through early April in several different years he has seen flocks, generally of about 50 birds, arriving at the north shore of Lake Athabasca after they had crossed the lake on a northeasterly course.

FORT CHIPEWYAN AREA, ALBERTA:

McDonald also reports several times having seen in early spring flocks that reached the north shore of this part of Lake Athabasca after following a northeasterly course. He has not seen ptarmigan crossing this lake in the fall.

His observations include some points of interest apart from the matter of the direction of movements. He reports that flights over the lake took place early in the morning, the birds flying only about $1.5 \mathrm{~m}$ above the frozen lake. After making landfall, the ptarmigan would feed for an hour or so. Then one bird flying off inland would be followed by others in increasing numbers until the whole flock moved on.

\section{CREIGHTON, SASKATCHEWAN:}

A single flock of about two thousand birds was seen flying northward at a height of about $90 \mathrm{~m}$ above the ground in March 1973. 


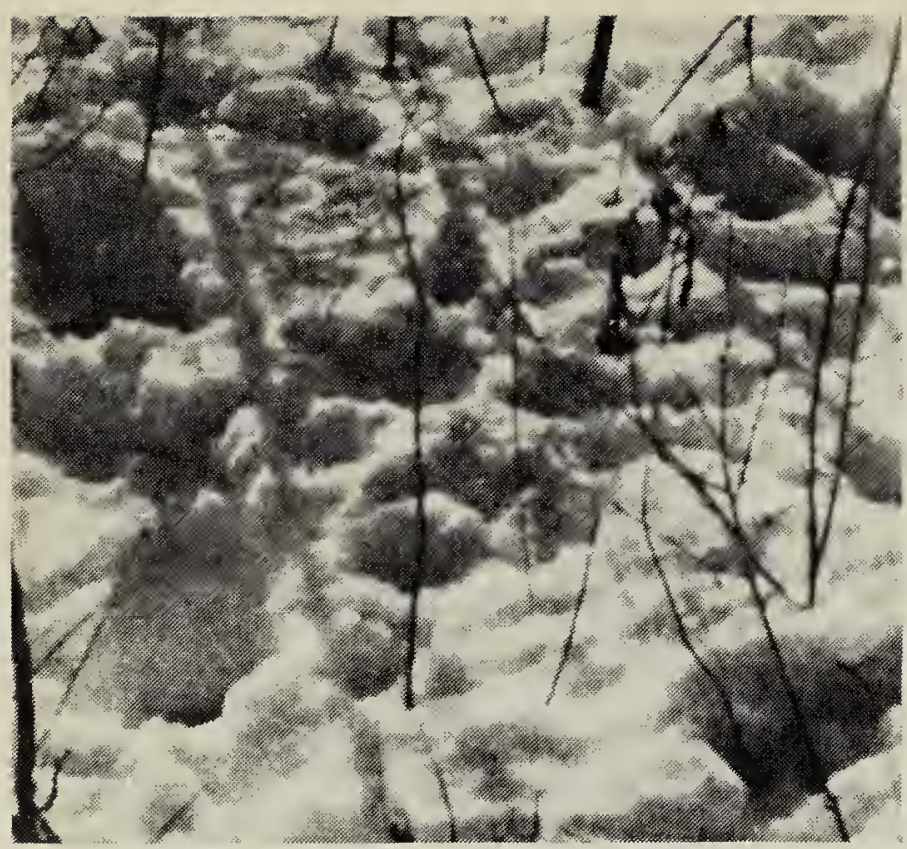

Snow holes where Willow Ptarmigan spent the night near Ft. McMurray, Alberta

E. Otto Höhn

\section{Fall movements}

URANIUM CITY AREA, SASKATCHEWAN: Two flocks, each of about fifteen birds, were seen leaving the north shore of Lake Athabasca on a southwesterly course in an apparent lake crossing flight in early December, 1975.

FORT RESOLUTION, NORTHWEST TERRITORIES:

In October 1976, "hundreds of ptarmigan" were seen flying in a southwesterly direction along the shore of Great Slave Lake.

\section{YELLOWKNIFE BAY, NORTHWEST TERRITORIES:}

In the early winter of 1974-75, several flocks each of about seven birds, were seen heading out over Great Slave Lake in a southerly direction.

It is possible that observers not particularly interested in the exact direction of the flights (as Mr. McDonald had become as a result of his observations) recorded only their general direction in the case of the reports from Creighton and Yellowknife Bay. These flights might in fact have conformed to the general northeast-southwest pattern.
The direction of migratory movements of ptarmigan observed in the area under consideration is apparently related to climatic and geographical factors. Mid-winter isotherms in this area lie further north in its western than in its eastern portion. ${ }^{13}$ Ptarmigan moving southwesterly in the fall will therefore reach a slightly milder climate sooner than if they travel in any other direction.

Since the southern boundary of the tundra north of the area under consideration slants farther south as one proceeds eastward (see Fig. 1), ptarmigan moving toward the breeding zone in late winter will have to traverse less boreal forest if they fly on a northeasterly rather than a northerly course.

\section{Predation on ptarmigan}

Various avian predators have been observed taking Willow Ptarmigan. ${ }^{5}$ To those previously listed may be added the report of a Short-eared Owl killing a full grown ptarmigan in one of the questionnaire replies. As kills by mammalian predators, though no doubt frequent, are rarely observed, a Shorttailed Weasel killing an adult ptarmigan and a Fisher carrying one in its mouth, which were reported in questionnaire replies, are noteworthy.

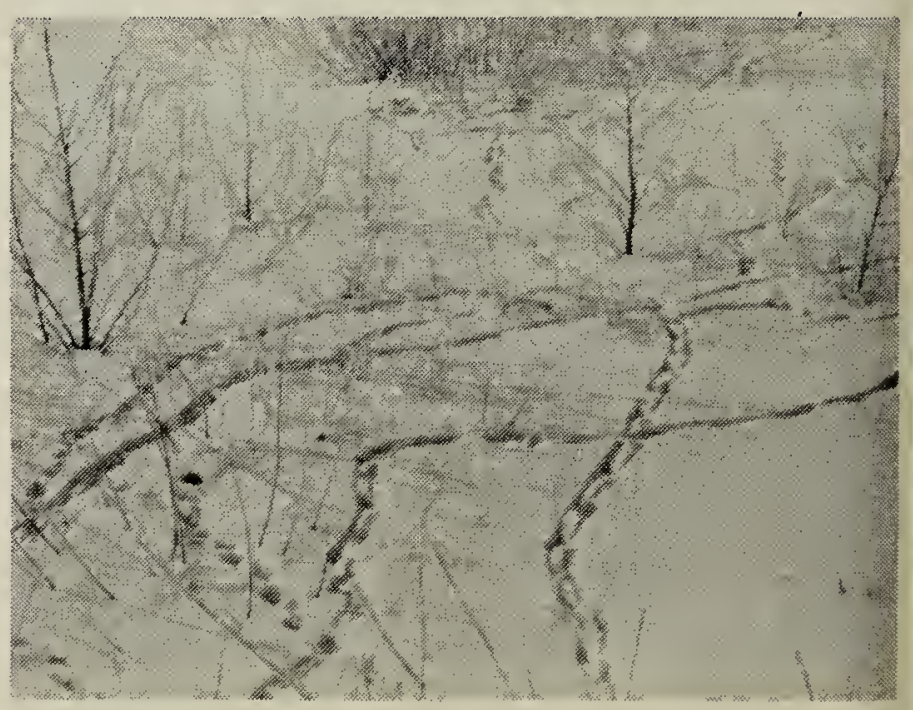

Ptarmigan tracks near Uranium City, Saskatchewan.

E. Otto Höhn 
the associated greater cold tolerance probably favours the survival of males on the tundra as compared to females. There is some evidence of autumnal androgen secretion in male Willow Ptarmigan. Display calls and occasional territorial behaviour were observed in these birds in Alaska by Weeden, who noted no sexual behaviour in hens at this time. ${ }^{12}$ This androgen-dependent territoriality would strengthen the attachment of males to the breeding areas and tend to inhibit their departure from it in the fall or reduce the distance to which they move away from it.

Lastly, adult males would be likely to arrive on the breeding grounds in the spring before younger males which (on the basis of the findings of Hoffman and Braun) have wintered farther away. ${ }^{4}$

\section{Acknowledgements}

I wish to thank the Superintendent of Game, Government of the Northwest Territories, and Directors of the Fish and Wildlife Divisions of the Governments of Alberta, Saskatchewan and Manitoba, for distribution of my questionnaires and above all the 23 game biologists, game wardens, conservation officers and individuals who responded to my questionnaires.

I am also obliged to those who supplied me with data on sexed ptarmigan in a number of museum collections.

'Atlas of Alberta. 1969. Compiled by the Department of Geography, University of Alberta, Univ. of Alberta Press, in association with Univ. of Toronto Press, Edmonton and Toronto.

'BERGERUD, A.T., T. PETERS and R. McGRATH. 1963. Determining the sex and age of Willow Ptarmigan in Newfoundland. J. Wildl. Mgmt. 27:700-711.
${ }^{3}$ Canadian Oxford Atlas. 1967. 2nd edition. Oxford University Press, Toronto, 93 pp.

${ }^{4}$ HOFFMAN, R.W. and C.E. BRAUN. 1975. Migration of a wintering population of White-tailed Ptarmigan in Colorado. J. Wilkl. Mgmt. 39:485-490.

${ }^{5}$ HÖHN, E.O. 1980. Die Schneehühner (The Ptarmigans). Wittenberg, Ziemsen. 128 pp.

IIRVING, L., G.C. WEST, L. PEYTON and S. PANEAK. 1967. Migration of Willow Ptarmigan in Arctic Alaska. Arctic 20:77-85.

7JENKINS, D., A. WATSON and G.R. MILLER. 1963. Population studies on Red Grouse, Lagopus lagopus scoticus (Lath.) in northeast Scotland. J. Anim. Ecol. 32:217-276.

${ }^{8}$ PORSILD, A.E. 1943. Birds of the MacKenzie Delta. Can. Field, Nat. 57:1935.

${ }^{9}$ PULLIAINEN, E. 1968. On the sex determination and weight of Willow Grouse (Lagopus lagopus) in Finnish Lapland. Suom. Riista 20:43-49. (Finnish with English summary).

10SOPER, J.D. 1942. The birds of Wood Buffalo Park and vicinity, northern Alberta, and district of MacKenzie, N.W.T., Canada. Trans. R. Can. Inst. 24:1-97.

"WEEDEN, R.B. 1964. Spatial segregation of sexes in Rock and Willow Ptarmigan in winter. Auk 81:534-541.

${ }^{12}$ WEEDEN, R.B. 1965. Grouse and Ptarmigan in Alaska. Alaska Department of Fish and Game, Juneau, Alaska, mimeo. $110 \mathrm{pp}$.

${ }^{13}$ WEEDEN, R.B. 1969. Foods of Rock and Willow Ptarmigan in central Alaska with comments on interspecific competition. Auk 26:271-280.

${ }^{14}$ WEST, G.C., R.B. WEEDEN, L. IRVING and J. PEYTON. 1970. Geographic variation in body size and weight of Willow Ptarmigan. Arctic 23:240-253. 